\title{
Stimulating Home Environment for Early Childhood Development by Household Play Materials for Under 5 Rural Children in Forest Buffer Zone of Wardha District
}

\author{
Manoj Patil ${ }^{1}$, Shital Telrande ${ }^{2}$, Mahalaqua Nazli Khatib ${ }^{3}$, Shilpa Gaidhane ${ }^{4}$, Deepak Saxena ${ }^{5}$, \\ Pankaj Bhardwaj6, B. Unnikrishnan7, Abhay Gaidhane ${ }^{8}$, Quazi Syed Zahiruddin ${ }^{9}$
}

\begin{abstract}
${ }^{1}$ Department of Research and Development, Datta Meghe Institute of Medical Sciences, Wardha, Maharashtra, India. ${ }^{2}$ Department of Research and Development, Datta Meghe Institute of Medical Sciences, Wardha, Maharashtra, India. ${ }^{3}$ Department of Physiology, Jawaharlal Nehru Medical College, Datta Meghe Institute of Medical Sciences, Wardha, Maharashtra, India. ${ }^{4}$ Department of General Medicine, Jawaharlal Nehru Medical College, Datta Meghe Institute of Medical Sciences, Wardha, Maharashtra, India. ${ }^{5}$ Department of Epidemiology; Indian Institute of Public Health-Gandhinagar (IIPHG) and Jawaharlal Nehru Medical College; Datta Meghe Institute of Medical Sciences, Wardha, Maharashtra, India. ${ }^{6}$ Community Medicine and Family Medicine, AIIMS, Jodhpur, Rajasthan, India. ${ }^{7}$ Department of Community Medicine, Kasturba Medical College, Manipal University, Mangalore, Karnataka, India. ${ }^{8}$ Department of Community Medicine, Jawaharlal Nehru Medical College, Datta Meghe Institute of Medical Sciences, Wardha, Maharashtra, India. ${ }^{9}$ Department of Community Medicine, Jawaharlal Nehru Medical College, Datta Meghe Institute of Medical Sciences, Wardha, Maharashtra, India.
\end{abstract}

\section{ABSTRACT}

\section{BACKGROUND}

Home Environment of a child comprises of toys, books and stimulating play materials which are critical for promoting early development. Parents, family and atmosphere at home play a key role in stimulating child's physical, cognitive and socio-emotional developments. This assessment was done in rural settings of forest buffer zone of Bor Tiger Sanctuary in Vidarbha to have a baseline picture about availability of play materials at households that promote child development and parent's view about these play materials.

\section{METHODS}

This was a cross-sectional survey which included assessment of 894 households in 45 villages from Seloo block of Wardha district. Survey tools included pretested questionnaire and home observation checklist which was administered at home visit and during interviews of parent-child dyads. Data was collected in android based ODK app and exported to server. Data imported from server was analysed using STATA-11.

\section{RESULTS}

Availability of play materials as represented by Mean Item Availability Score (MIAS) was significantly associated with family structure, wealth index and parent's education and occupation. Though $84.2 \%$ households had materials for moving around and outdoor play, only $26.9 \%$ households had materials for promoting coordinated gross-motor movements, $41.6 \%$ households had materials meant for stacking, constructing. Only 19.8\% households had materials for learning shapes and colours, $29.8 \%$ households had picture books/charts, $32.4 \%$ households had materials for drawing and writing and only $11.3 \%$ children had materials promoting counting.

\section{CONCLUSIONS}

Obvious gap can be seen in terms of paly materials available for under 5 children in rural and urban settings. Remote rural areas in this region need a well framed parenting program to sensitise parents about Early Child Development that can be blended with the existing ICDS program activities.

\section{KEY WORDS}

Play and Learning Materials, Early Childhood Development, Mean Item Availability Score (M-IAS), Under-Five Children
Corresponding Author: Dr. Mahalaqua Nazli Khatib, Department of Physiology and Head Division of Evidence Synthesis, Centre of Excellence, School of Epidemiology and Public Health, Datta Meghe Institute of Medical Sciences, Deemed to be University) Wardha, Maharashtra, India.

E-mail: nazli.786@rediffmail.com

DOI: 10.14260/jemds/2020/291

Financial or Other Competing Interests: Khatib Reports Grants from Grand Challenge Canada, outside the Submitted Work.

\section{How to Cite This Article:}

Patil M, Telrande S, Khatib MN, et al. Stimulating home environment for early childhood development by household play materials for under 5 rural children in forest buffer zone of Wardha district. J. Evolution Med. Dent. Sci. 2020;9(16): 1336-1340 DOI:
Submission 26-12-2019,

Peer Review 30-03-2020,

Acceptance 06-04-2020,

Published 20-04-2020. 


\section{BACKGROUND}

In early years of life, child is mostly exposed to home environment, play materials available at home and surroundings conditions which play a role in child's early development. Young children spend most their time at home and home environments critically influence the overall development of children.[1] Family members interact with children through different types of play materials and these interactions are influenced by the availability and quality of those play materials.[1] The critical indicators for overall quality of home environment is availability of stimulating objects, books and play materials which eventually affect development of child in early age. Thus, role of family and home environment is obvious in Early Child Development (ECD) and hence the necessity of stimulating material in the early years. [2] Early childhood development (ECD) refers to the biological and psychological changes occurring in children between conception and age of six. More than $80 \%$ of brain growth is completed by this period and every aspect of a child's life is influenced by it. Optimum conditions are necessary for a child to develop normally and lay the foundations for a good life. The optimum conditions consist of a number of aspects leading to appropriate nutrition, health and parenting. Main causes of underdevelopment in India include inadequate feeding practices, inadequate care and poor attention to illness due to the low status of Indian women, poverty, and less birth spacing.[3] India's largest ECD programme, the Integrated Child Development Services scheme (ICDS) offers a package of services from local Anganwadi (childcare) centres to children, adolescent girls, pregnant women and lactating mothers. The package for children includes supplementary nutrition, growth monitoring, primary healthcare, immunization, referral and non-formal pre-school education. But significant problems with the ICDS services include inadequate coverage, poor opening hours and neglect of child development activities targeted on under-threes. Only 25\% parents report about getting any kind of service from ICDS in a year.[4]

The social and emotional care which includes stimulation, affection, security and love is also a final key component affecting childhood development. [5] For babies and young children, socio-emotional care includes involving in conversation with them through look, touch and speech, and responding to them positively. Older children get to it through quality pre-school education and day care services.[5,6] For every child, positive care includes parental involvement, spending time together, being listened to, avoiding negatives like exposure to stress and violence.[6,7] The researchers have very limited data on stimulation and care in early childhood development. But good care is unlikely in the circumstances of many children and families. Majority of parents are engaged in full time work, shortly after birth, and younger siblings are given the responsibility of looking after children. Rural habitations in Vidarbha are characterized by crowding, lack of clean water, poor sanitation facilities, exposure to animal wastes, human excreta and agricultural pesticides. The quality of childcare is affected by time that parents spend with child, which in turn depends on a number of diverse factors that include financial status of family, birth spacing, domestic responsibilities of mothers etc. Most women work in the informal sectors like construction, farming, as domestic helpers. Sparing much time to look after a new baby is not affordable. Many women keep working right up to the childbirth and go back to work a within a few days of childbirth. In this situation, they either take the child to workplace or leave the child at home, often with older siblings. The child is deprived of essential care in this period. This places a lot of physical and emotional stress on the mother and also threatens the growth and survival of the child.[5] Availing necessary age specific stimulating paly materials mostly remains a dream for these parents. This study was conducted to find out the availability of play and learning materials at households of under-5 children and parent's perceptions regarding the importance of stimulating home environment in early childhood development.

\section{METHODS}

\section{Study Population}

This cross-sectional survey was conducted in 45 villages in forest buffer zone of Bor tiger sanctuary in Wardha district of Maharashtra. Total 894 households with children between 12 to 60 months age were purposively selected and included in the study. These villages are located in the forest buffer zone of Bor Tiger sanctuary in Maharashtra, covering a population of around 30841 and about $15 \%$ of this population is tribal. Majority of population is engaged in agriculture and forestbased activities for earning their livelihood. Though many villages have good access by road, they have limited transportation facilities and Anganwadi centres are the only early child development facility available for under-5 children in these villages.

\section{Data Collection}

Data collection tool included two components, a Parent's Questionnaire and Home Observation Checklist. Tool comprised of questions on general information about household and family, specific questions related to play and learning materials available at home for the children and perception of parents or caregivers regarding the role of stimulating home environment for Early Childhood Development. The tool was translated in local language and was back translated to English. Data collection tool was piloted in few households and adapted to local context. Final version was adapted and prepared in android based ODK app for data collection. Data on village profile was collected from Local Governing bodies (gram-panchayat) and list of all under-5 children was obtained from Anganwadi workers of the village. All the households with children in the age of 1260 months were selected. Data was collected by trained and certified research assistants at home visits through personal interview and home observation. A list of play and learning materials was prepared and the items were grouped under 10 different categories of materials. At least one "age appropriate" item available from one group of materials was considered "Available" for that child/household. Primary Caregivers of the children, mostly mothers were interviewed. Availability of total 30 items was assessed. Score "1" was assigned for each available item and "0" was assigned if item 
is not available. Total 'Item Availability Score (IAS)' was calculated for each household and 'Mean Item Availability Score (MIAS)' was then calculated for each subgroup. Data on perception of parents was collected using a questionnaire with Likert-type scale for responses to questions.

\section{Data Analysis}

Total 894 households participated in the study from 45 villages having children in the age group of 12 to 60 months. The data from ODK server was imported and analysed using STATA 11. The key outcome variables included availability of the play material at home, Mean Item Availability Score and perception of caregivers regarding importance of stimulating home environment for ECD. The key predictors included education and occupation of mother, education and occupation of father, wealth index and family structure. Outcome variables were presented as proportion with confidence interval. Item Availability Scores for groups were presented as Means (MIAS) with standard deviations. ANOVA was used to test the significance.

\section{RESULTS}

Total 894 households were assessed which included 456 (51\%) households with male children and 438 (49\%) households with female children. In household with more than one child in the age of 12-60 months, assessment was done only for the oldest child. About 446 (49.9\%) children belonged to the age group of 37 to 60 months, 228 (25.5\%) were between 25 to 36 months and 220 (24.6\%) were aged 12-24 months. Father's education, Mother's education, Occupation of father, Occupation of mother, Wealth and Family size was found statistically significant with Mean Item Availability Scores (MIAS) of the households $(\mathrm{p}<0.05)$.

Materials for moving around and outdoor play (e.g. balls, bats, etc.) were available at 753 (84.2\%) households of under-5 children. Regarding perception, 648 (72.5\%) parents 'Strongly Agree' that materials for moving around and outdoor play help to improve physical activity/motor development of child. Only 240 (26.9\%) households had Materials for promoting coordinated gross-motor movements like Puller toys, Kids Tricycle etc. Regarding perception, 462 (51.7\%) parents 'Strongly Agree' that such materials help in promoting coordinated gross motor movements. Materials meant for stacking, constructing, building (blocks) were available for children in 372 (41.6\%) households. 356 (39.8\%) parents 'Strongly Agree' that such materials help to improve hand eye coordination and cognitive development of child. Materials which make/play music were available in 800 (89.5\%) households of under -5 children. 428 (47.9\%) parents 'Strongly Agree' and 395 (44.2\%) parents 'agree' that such materials help in improving child's sensorial development. Materials for pretending/mimicking (e.g. dolls, kitchen-set, etc.) were available at 548 (61.3\%) households. 521 (58.3\%) parents 'Strongly Agree' that such materials help in improving socioemotional development of child. Materials for learning shapes and colours were available with 177
(19.8\%) households. 498 (55.7\%) parents 'Strongly Agree' that such materials help to improve sensorial and cognitive development of child. Picture books/charts for children were available in 266 (29.8\%) households. 458 (51.2\%) parents 'Strongly Agree' that picture books/charts are useful for improving cognitive and language development of child. Materials for drawing/writing were available in 290(32.4\%) households. 505 (56.5\%) parents 'Strongly Agree' that materials for drawing/writing help to improve fine motor and creative/aesthetic development of child along with cognitive development. Materials for promoting reading/Language development were available in 172 (19.2\%) households. 402 (45\%) parents 'Strongly Agree' that story books, singing songs for child, playing videos/songs on mobile help in cognitive and language development of child. Materials for promoting counting for child were available only at $101(11.3 \%)$ household whereas 443 (49.6\%) parents 'Strongly Agree' that such things help to improve the cognitive development and numerical sense of child.

\begin{tabular}{|c|c|c|c|}
\hline \multicolumn{2}{|c|}{ Participant Characteristics } & No $(N=894)$ & Percentage \\
\hline \multirow{2}{*}{ Sex of the child } & Male & 456 & 51.0 \\
\hline & Female & 438 & 49.0 \\
\hline \multirow{3}{*}{ Age of the child } & 12 to 24 months & 220 & 24.6 \\
\hline & 25 to 36 months & 228 & 25.5 \\
\hline & 37 to 60 months & 446 & 49.9 \\
\hline \multirow{5}{*}{ Education of Father } & Illiterate & 38 & 4.2 \\
\hline & Primary education & 190 & 21.3 \\
\hline & SSC & 324 & 36.2 \\
\hline & HSC & 251 & 28.1 \\
\hline & Graduation and above & 91 & 10.2 \\
\hline \multirow{4}{*}{ Occupation of Father } & Farmer & 619 & 69.2 \\
\hline & $\begin{array}{c}\text { Govt. Employee/ Private } \\
\text { Firm Employee }\end{array}$ & 21 & 2.4 \\
\hline & Businessman & 65 & 7.3 \\
\hline & Other daily wager & 189 & 21.1 \\
\hline \multirow{5}{*}{ Education of mother } & Illiterate & 45 & 5.06 \\
\hline & Primary education & 232 & 25.93 \\
\hline & SSC & 292 & 32.64 \\
\hline & $\mathrm{HSC}$ & 253 & 28.28 \\
\hline & Graduation and above & 72 & 8.09 \\
\hline \multirow{5}{*}{ Occupation of mother } & Farmer & 66 & 7.4 \\
\hline & Other daily wager & 105 & 11.8 \\
\hline & $\begin{array}{l}\text { Govt. employee/Private } \\
\text { firm employee }\end{array}$ & 18 & 2.0 \\
\hline & Business & 25 & 2.8 \\
\hline & Home maker & 679 & 76.0 \\
\hline \multirow{3}{*}{ No. of family members } & $<4$ & 262 & 29.3 \\
\hline & $4-5$ & 404 & 45.2 \\
\hline & $>5$ & 228 & 25.5 \\
\hline \multirow{5}{*}{ Wealth Index } & Poorest & 219 & 24.48 \\
\hline & Poorer & 169 & 18.95 \\
\hline & Middle & 171 & 19.13 \\
\hline & Richer & 171 & 19.13 \\
\hline & Richest & 164 & 18.31 \\
\hline \multicolumn{4}{|c|}{ Table 1. Characteristics of Study Population } \\
\hline
\end{tabular}

\begin{tabular}{|c|c|c|}
\hline Items & No. $(\mathrm{N}=894)$ & Proportion (CI) \\
\hline $\begin{array}{l}\text { Materials for moving around and outdoor } \\
\text { play (balls, bats, etc.) }\end{array}$ & 753 & $84.2(81.8-86.6)$ \\
\hline $\begin{array}{l}\text { Materials for promoting coordinated gross- } \\
\text { motor movements }\end{array}$ & 240 & $26.9(24.0-29.8)$ \\
\hline $\begin{array}{c}\text { Materials meant for stacking, constructing, } \\
\text { building (blocks) }\end{array}$ & 372 & $41.6(38.4-44.8)$ \\
\hline Materials which make/play music & 800 & $89.5(87.5-91.5)$ \\
\hline $\begin{array}{l}\text { Materials for pretending/mimicking } \\
\text { (dolls, kitchen-set, etc.) }\end{array}$ & 548 & $61.3(58.1-64.5)$ \\
\hline Materials for learning shapes and colours & 177 & $19.8(17.2-22.4)$ \\
\hline Picture books/charts for children & 266 & $29.8(26.8-32.8)$ \\
\hline Materials for drawing/writing & 290 & $32.4(29.3-35.5)$ \\
\hline $\begin{array}{c}\text { Materials for promoting reading/Language } \\
\text { development }\end{array}$ & 172 & $19.2(16.6-21.8)$ \\
\hline Materials for promoting counting & 101 & $11.3(9.2-13.4)$ \\
\hline
\end{tabular}




\begin{tabular}{|c|c|c|c|c|}
\hline $\begin{array}{c}\text { Participant } \\
\text { Characteristics }\end{array}$ & No (\%) & MIAS (SD) & F-Test & P-Value \\
\hline \multicolumn{5}{|c|}{ Age of the child } \\
\hline 12 to 24 months & $220(24.6)$ & $18.97(4.89)$ & \multirow{3}{*}{0.89} & \multirow{3}{*}{0.409} \\
\hline 25 to 36 months & $228(25.5)$ & $19.17(4.79)$ & & \\
\hline 37 to 60 months & $446(49.9)$ & $18.98(4.77)$ & & \\
\hline \multicolumn{5}{|c|}{ Education of Father } \\
\hline Illiterate & $38(4.2)$ & $16.08(5.13)$ & \multirow{5}{*}{42.67} & \multirow{5}{*}{0.000} \\
\hline Primary education & $190(21.3)$ & $18.21(4.77)$ & & \\
\hline SSC & $324(36.2)$ & $19.03(4.82)$ & & \\
\hline HSC & $251(28.1)$ & $21.19(4.94)$ & & \\
\hline Graduation and above & $91(10.2)$ & $24.86(4.65)$ & & \\
\hline \multicolumn{5}{|c|}{ Occupation of Father } \\
\hline Farmer & $619(69.2)$ & $19.70(4.51)$ & \multirow{4}{*}{65.1} & \multirow{4}{*}{0.000} \\
\hline $\begin{array}{l}\text { Govt. Employee/ Private Firm } \\
\text { Employee }\end{array}$ & $21(2.4)$ & $25.60(6.79)$ & & \\
\hline Businessman & $65(7.3)$ & $24.50(4.77)$ & & \\
\hline Other daily wager & $189(21.1)$ & $16.30(5.13)$ & & \\
\hline \multicolumn{5}{|c|}{ Education of mother } \\
\hline Illiterate & $45(5.06)$ & $16.50(4.57)$ & \multirow{5}{*}{51.8} & \multirow{5}{*}{0.000} \\
\hline Primary education & $232(25.93)$ & $20.70(4.76)$ & & \\
\hline SSC & $292(32.64)$ & $21.10(4.83)$ & & \\
\hline HSC & $253(28.28)$ & $24.40(4.35)$ & & \\
\hline Graduation and above & $72(8.09)$ & $26.50(6.78)$ & & \\
\hline \multicolumn{5}{|c|}{ Occupation of mother } \\
\hline Farmer & $66(7.4)$ & $17.50(4.76)$ & \multirow{5}{*}{57.21} & \multirow{5}{*}{0.000} \\
\hline Other daily wager & $105(11.8)$ & $14.70(4.89)$ & & \\
\hline $\begin{array}{l}\text { Govt. employee/Private firm } \\
\text { employee }\end{array}$ & $18(2)$ & $26.50(5.71)$ & & \\
\hline Business & $25(2.8)$ & $24.70(4.65)$ & & \\
\hline Home maker & $679(76)$ & $20.50(4.49)$ & & \\
\hline \multicolumn{5}{|c|}{ No. of family members } \\
\hline$<4$ & $262(29.3)$ & $19.40(4.65)$ & \multirow{3}{*}{50.6} & \multirow{3}{*}{0.000} \\
\hline 4 to 5 & $404(45.2)$ & $22.50(5.65)$ & & \\
\hline$>5$ & $228(25.5)$ & $24.50(6.78)$ & & \\
\hline \multicolumn{5}{|c|}{ Wealth Index } \\
\hline Poorest & $219(24.48)$ & $16.46(4.53)$ & \multirow{5}{*}{37.3} & \multirow{5}{*}{0.000} \\
\hline Poorer & $169(18.95)$ & $17.8(4.12)$ & & \\
\hline Middle & 171 (19.13) & $19.7(5.11)$ & & \\
\hline Richer & $171(19.13)$ & $20.56(5.85)$ & & \\
\hline Richest & $164(18.31)$ & $21.84(4.35)$ & & \\
\hline \multicolumn{5}{|c|}{$\begin{array}{c}\text { Table 3. Mean Item Availability Scores (MIAS) } \\
\text { and Results of ANOVA (F-Test) }\end{array}$} \\
\hline
\end{tabular}

\begin{tabular}{|c|c|c|c|c|c|}
\hline & \multicolumn{5}{|c|}{$\begin{array}{l}\text { I play with my child. I think materials for moving around and outdoor play } \\
\text { (balls, bats, etc.) helps to improve their physical activity/motor } \\
\text { development. }\end{array}$} \\
\hline & Strongly Disagree & Disagree & Agree & Strongly Agree & Can't say \\
\hline . $(\%)$ & $3(0.3 \%)$ & $5(0.6 \%)$ & 225 (25.2\%) & 648 (72.5\%) & \\
\hline Que.2 & \multicolumn{5}{|c|}{$\begin{array}{l}\text { I think materials like tricycle/Puller toy help for promoting coordinated } \\
\text { gross-motor movements. }\end{array}$} \\
\hline & Strongly Disagree & Disagree & Agree & Strongly Agree & Can't say \\
\hline o. (\%) & $17(1.9 \%)$ & $12(1.3 \%)$ & 370 (41.4\%) & $462(51.7 \%)$ & \\
\hline Que.3 & \multicolumn{5}{|c|}{$\begin{array}{l}\text { I think materials meant for stacking, constructing, building (blocks) help to } \\
\text { improve child's hand eye coordination and cognitive development. }\end{array}$} \\
\hline & Strongly Disagree & Disagree & Agree & & \\
\hline & $23(2.6 \%)$ & $34(3.8 \%)$ & 355 (39.7\%) & 356 (39.8\%) & 126 (14.1\%) \\
\hline Que.4 & \multicolumn{5}{|c|}{$\begin{array}{l}\text { Materials which make/play music help in improving child's sensorial } \\
\text { development. }\end{array}$} \\
\hline & & Disagree & & & \\
\hline & 11 (1.2\%) & $26(2.9 \%)$ & 395 (44.2\%) & 428 (47.9\%) & \\
\hline Que.5 & \multicolumn{5}{|c|}{$\begin{array}{c}\text { Materials for pretending/mimicking (dolls, kitchen-set, etc.) help in socio- } \\
\text { emotional development of child. }\end{array}$} \\
\hline & Strongly Disagree & & & & \\
\hline No. (\%) & $3(0.3 \%)$ & $13(1.5 \%)$ & 304 (34\%) & 521 (58.3\%) & \\
\hline Que.6 & \multicolumn{5}{|c|}{$\begin{array}{c}\text { Materials for learning shapes and colours help in sensorial and cognitive } \\
\text { development of child. }\end{array}$} \\
\hline & Strongly Disagree & Disagree & & Strongly Agree & \\
\hline Vo. $(\%)$ & $7(0.8 \%)$ & $18(2 \%)$ & 298 (33.3\%) & $498(55.7 \%)$ & \\
\hline Que.7 & \multicolumn{5}{|c|}{$\begin{array}{c}\text { Picture books/charts for children help in improving cognitive and language } \\
\text { development of child. }\end{array}$} \\
\hline & Strongly Disagree & Disagree & & & \\
\hline & $5(0.6 \%)$ & $12(1.3 \%)$ & 397 (44.4\%) & 458 (51.2\%) & \\
\hline Que.8 & \multicolumn{5}{|c|}{$\begin{array}{c}\text { Materials for drawing/writing help in fine motor and creative-aesthetic } \\
\text { development of child. }\end{array}$} \\
\hline & Strongly Disagree & & & & \\
\hline & $12(1.3 \%)$ & $14(1.6 \%)$ & $304(34 \%)$ & 505 (56.5\%) & $59(6.6 \%)$ \\
\hline Que.9 & \multicolumn{5}{|c|}{$\begin{array}{l}\text { Story books, singing songs for child or play videos/songs on mobile help in } \\
\text { cognitive and language development of child. }\end{array}$} \\
\hline & Strongly Disagree & & & & \\
\hline & $6(0.7 \%)$ & $33(3.7 \%)$ & 399 (44.6\%) & $402(45 \%)$ & $54(6 \%)$ \\
\hline 2ue.10 & \multicolumn{5}{|c|}{$\begin{array}{l}\text { Materials for promoting counting help in improving cognitive and } \\
\text { numerical sense development of child. }\end{array}$} \\
\hline & & & & & \\
\hline & & & & & \\
\hline verage & $9(1 \%)$ & $18(2 \%)$ & $345(38.6 \%)$ & $472(52.8 \%)$ & $50(5.6 \%)$ \\
\hline & $\begin{array}{l}\text { Ie 4. Percep } \\
\text { Importar }\end{array}$ & . & He & ent & \\
\hline
\end{tabular}

\section{DISCUSSION}

This survey assessed perceptions of parents and home environment considering the availability of stimulating play and learning materials for under 5 children. Though materials for moving around and outdoor play was available at majority of $(84.2 \%)$ households, comparatively fewer $(26.9 \%)$ households had materials for promoting coordinated gross-motor movements and materials meant for stacking, constructing, building. Though most of the children $(89.5 \%)$ had materials which make/play music, materials for pretending/mimicking (61.3\%), materials for learning shapes and colours, drawing and writing, counting and numerical sense were available to very few children. This points to the fact that a lot of children lack the necessary age appropriate play and learning materials. Though a significant number of parents agree and perceive the need of specific play and learning materials, their availability at home is not considered a priority. This may be due to lack of awareness among parents in addition to poverty and a number of socioeconomic factors. Availability of stimulating play materials was significantly associated with education \& occupation of fathers, education and occupation of mothers, wealth index of family and family structure.

\section{CONCLUSIONS}

This survey was conducted in an attempt to find favourability of home environment for the development of child. There is enormous scope for improvement in the home environment of under 5 children in remote rural areas of Wardha district. Additional research is needed that connects these indicators with actual child development variables. However, preliminary results from this study clearly indicate that these rural settings need improvements for promoting early childhood development. Also, the parents need a lot of awareness and support to improve their parenting skills that will ultimately help in stimulating child's development. There is an obvious need of locally adapted and culturally acceptable Early Childhood Development programme including parenting interventions for the rural population of Wardha district and population from adjoining region with similar context.

\section{REFERENCES}

[1] Selim I. Significance of home environments as proxy indicators for early childhood care and education. EFA Global Monitoring Report UNESCO 2006.

[2] Nadeem S, Rafique G, Khowaja L, et al. Assessing home environment for early child development in Pakistan. Child Care Pract 2014;20(2):194-206.

[3] Unicef. The State of the World's children 2008: child survival. UNICEF 2007.

[4] Ministry of health and family welfare. Government of India (2005/6). National Family Health Survey (NFHS-3). http://www.nfhsindia.org/abt.html. 
[5] Citizens' initiative for the rights of children under six (2006): focus on children under six. http://www.righttofoodindia.org.

[6] The impact of early adversity on children's development. National Symposium on Early Childhood Science and Policy. http://www.developingchild.harvard.edu.
[7] Walker SP, Wachs TD, Gardner JM, et al. Child development: risk factors for adverse outcomes in developing countries. Lancet 2007;369(9556):145-57. 